\title{
Association of $\mathrm{Cu}\left(\mathrm{NO}_{3}\right)_{2}$ with Kryptofix-221 in Mixed (MeOH-DMF) Solvents at Different Temperatures
}

\author{
E. A. Gomaa*, B. M. Al-Jahdali \\ Chemistry Department, Faculty of Science, Mansoura University, Mansoura, 35516, Egypt
}

\begin{abstract}
Abtract New equation was applied for the Calculation of association constant (KA) from the reaction of $\mathrm{Cu}(\mathrm{NO} 3)_{2}$ with Kryptofix-221 in mixed (MeOH-DMF) and in absence and Presence of ligand at different temperatures. From the experimental results, the molar conductance $(\Lambda)$ were evaluated. The limiting molar conductance $\left(\Lambda_{\mathrm{o}}\right)$ were also estimated. Gibbs free energies of association $\left(\Delta \mathrm{G}_{\mathrm{A}}\right)$ was also estimated, Moreover, recalculation of $\left(\mathrm{K}_{\mathrm{A}}\right)$ was achieved by applying Shedlovsky and Fouss-Kraus extrapolation methods. In addition, the molar solvated $(\mathrm{V})$, Van der Waals $\left(\mathrm{V}_{\mathrm{W}}\right)$, electrostriction $\left(\mathrm{V}_{\mathrm{e}}\right)$ and apparent molar $\left(\varnothing_{\mathrm{v}}\right)$ volmes were calculated. Also, the enthalpy change $(\Delta \mathrm{H})$ and the entropy change $(\mathrm{T} \Delta \mathrm{S})$ for $\mathrm{Cu}\left(\mathrm{NO}_{3}\right)_{2}$ were calculated. The degree of dissociation $(\alpha)$ were also calculated. All the results were discussed in view of ion-solvent interactions.
\end{abstract}

Keywords Association, Kryptofix-221-Dissociation, Molar Solvated Volume, Van der Waals Volume, Electrostriction Volume, Free Energy of Association, Denisties, Molar Fraction, Limiting Conductance

\section{Introduction}

Although metal cations play an important role both in chemistry and biology, the coordination chemistry of metals was completely ignored by chemists. However, the coordination chemistry of metal cations has mainly developed by the synthesis of crowns by Pedersen[Pedersen, (1967)][1]. The discovery of the crown ethers was followed by synthesis of macro bicyclic poly ethers containing three poly ether strands joined by two bridge head nitrogens[Lehn et al., (1971)][2].

These compounds have three-dimentional cavites which can accommodate a metal ion of a suitable size and from an inclusion complex.

These ligands which developed by Lehn and his- coworkers [Dietrich et al., (1969)][3], were called[2] Cryptands where[2] indicates the bicyclic ligand such as Kryptofix-221 which its structure is given in Fig (1). The crown compounds and their thia - and aza - derivatives have a considerable interest in terms of their complexation properties in solution with univalent and bivalent metals[Gokel, (1976)][4]. It is important to mention that the marocyclic crown ethers have many applications[Izatt et al., (1978)].[5] in biological activity, corrosion chemistry, analytical chemistry, phase - transfer catalysis and industrial production such as nuclear energy, electronics and electro-chemical

* Corresponding author: esam1947@yahoo.com (E.A.Gomaa) Published online at http://journal.sapub.org/ajfd Copyright (C) 2011 Scientific \& Academic Publishing. All Rights Reserved photosensitive materials[El-Dossouki; (1998)][6].On understanding the interactions between macrocyclic crown ethers such as Kryptofix-221 and metal cations in solutions, it requires the study of various parameters govering these interactions. The thermodynamic studies of these interactions gave important informations about their complexation reactions and the selectivities of these ligands towards different metal cations[Rounaghi et al., (1999)][7]. The abserved association constant values are known to be a composite quantities depending on specific and non-specific solute - solvent interactions. The separation of various interaction contributions is often very difficult process, beside that using mixed solvents it add another dimention to the problem[Mukhopadhyay et al., (1997)][8]. The multidentate macro molecules (MMM) which have been studied as ligands for $\mathrm{M}^{z+}$ were included natural antibiotics and synthetic compounds such as crowns and cyptands[9]. The macro molecular ligands had recently become more important to the chemistry of $\mathrm{M}^{\mathrm{Z}}$ than the conventional ligands, this was because they binded $\mathrm{M}^{\mathrm{Z}}$ effectively and rendered the latter soluble in non-polar solvents and because they were more relevant to the chemistry of $\mathrm{M}^{\mathrm{z}+}$ in biological system which thereinvolved essentially the macrobiomolecules.

A conductance study of the interaction between $\mathrm{Co}^{2+} \mathrm{Ni}^{2+}$, $\mathrm{Cu}^{2+}, \mathrm{Cd}^{2+}, \mathrm{Zn}^{2+}$ and $\mathrm{pb}^{2+}$ ions with Kryptofix-221, K-22\& $\mathrm{K}-222$ in different (acetonitrile-dimethyl sulfoxide) mixtures was carried out at various temperatures by Shamsipur[10]. The aim of the present work is to study the conductivity of $\mathrm{Cu}\left(\mathrm{NO}_{3}\right)_{2}$ in the absence and in presence of Kryptofix-221 using different molar ratios of (MeOH-DMF) mixed solvents 
at different temperaturas. By applying Shedlovsky,FoussKraus extrapolations[11] methods, we were able to evaluate the values of $\left(\Lambda_{0}\right),(\mathrm{KA}),(\Delta \mathrm{GA})$ and to make an acceptable discussion.

Finally, the crystal and molecular structures of about 200 metal halide complexes with oxygen-Containing crown ethers were investigated by Bel'sky[12].

The characteristic features of the formations of these complexes and their coordination fragments were discussed.

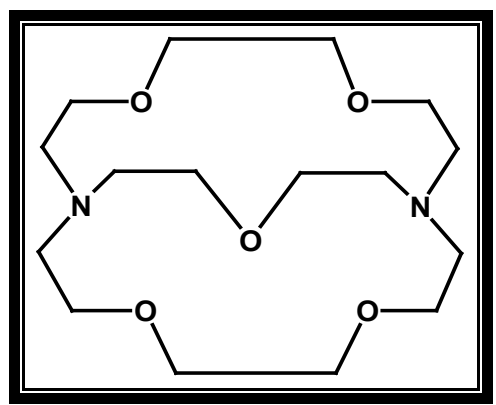

Figure 1. Kryptofix- 221 [4,7,13,16,21- pentaoxa-1.10-diazo-bicyclo $[8,8,5]$ tricosane $]$

\section{Experimental}

The aza-crown ether, Krypto fix-221[4.7.13.16.21-pantao xa - 1.10 - diazo bicyclo[8.8.5] tricosane) was supplied from Merck $\mathrm{Co}$. where as, cupper nitrate $\mathrm{Cu}\left(\mathrm{NO}_{3}\right)_{2}$ of high grade was supplied from BDH and it was used without any further purification.

The water content of the salt was determined by using (Mettler D1-18) Karl-Fisher titrator and it was found to be less than $\pm 0.01 \%$.

All solvents used MeOH\&DMF were BDH supplements used without any further purification.

The measurements of the specific conductivity of $\mathrm{Cu}\left(\mathrm{NO}_{3}\right)_{2}$ in the presence of Kryptofix-221 in all the mixed (MeOH - DMF) solvents were achieved at different temperatures using Beckman Conductivity Bridge Model No. (RE - 18A).

All the conductometric titrations were done using $1 \times 10^{-3}$ mol./lit. $\mathrm{Cu}\left(\mathrm{NO}_{3}\right)_{2}$ and $1 \times 10^{-4} \mathrm{~mol}$. /lit. of $332,44 \mathrm{gm} / \mathrm{mol}$, Kryptofix-221.

Spectrophotometrical contineous variation study of $\mathrm{Cu}\left(\mathrm{NO}_{3}\right)_{2}$ in the presence of Kryptofix-221 at different temperatures and in $20 \% \mathrm{MeOH}$ was achieved using Unicam UV-2-100 UV/Visible spectrometer $v 3.32$; at wave length of $\lambda \max (284 \mathrm{~nm})$.

\section{Results and Discussion}

The specific conductance values $\left(\mathrm{K}_{\mathrm{s}}\right)$ of different concentrations of $\mathrm{Cu}\left(\mathrm{NO}_{3}\right)_{2}$ in (MeOH-DMF) mixtures in the absence and in the presence of Kryptofix-221, were measured experimently and from which the values of molar conductance $(\Lambda)$ were calculated [Walter, (1976)] by using eq. (1):

$$
\Lambda=\frac{\left(\mathrm{K}_{\mathrm{s}}-\mathrm{K}_{\text {solv }}\right) \mathrm{Kcell} \times 1000}{c}
$$

Where (Ks) and (Ksolv) are the specific conductances of the solution and the solvent, respectively; (Kcell) is the cell constant and $(\mathrm{C})$ is the molar concentration of $\mathrm{Cu}\left(\mathrm{NO}_{3}\right)_{2}$.

The association constant value $\left(\mathrm{K}_{\mathrm{A}}\right)$ of different concentrations of $\mathrm{Cu}\left(\mathrm{NO}_{3}\right)_{2}$ in $(\mathrm{MeOH}-\mathrm{DMF})$ mixtures in the presence and in the absence of Kryptofix-221, were calculated by using eq.(2)

$$
\begin{gathered}
A^{+2}+2 B^{-} \rightleftharpoons A B_{2} \\
K_{A}=\frac{1-\alpha}{4 c m^{2} \gamma \pm^{2} \alpha^{3}} \\
\text { From, } \alpha=\frac{\Lambda s(z)}{\Lambda_{o}}
\end{gathered}
$$

Where $(\Lambda)$ is the molar conductance, $(\Lambda \mathrm{o})$ is the limiting molar conductance.

$$
K_{A}=\frac{\Lambda_{o}^{2}\left(\Lambda_{o}-\Lambda\right)}{4 c m^{2} \gamma \pm^{2} \Lambda^{3} s(z)}
$$

Where $(\alpha)$ is the degree of dissociation, Fuoss-Shedlovsky parameters $\left(\mathrm{S}, \mathrm{Z}\right.$ and $\mathrm{s}(\mathrm{z})$, activity coefficient $\left(\gamma_{ \pm}\right)$association constant $\left(\mathrm{K}_{\mathrm{A}}\right)$.

The evaluations of Gibbs free energies of association $\left(\Delta \mathrm{G}_{\mathrm{A}}\right)$ for $\mathrm{Cu}\left(\mathrm{NO}_{3}\right)_{2}$ with Kryptofix-221 in (MeOH -DMF) mixtures at different temperatures, were gained according to eq.(3).

[Kappenstein, (1974) ][13].

$$
\begin{aligned}
\Delta \mathrm{G}_{\mathrm{A}} & =-2.303 \mathrm{RT} \log \mathrm{K}_{\mathrm{A}} \\
\Delta \mathrm{G}_{\mathrm{A}} & =\Delta \mathrm{H}_{\mathrm{A}}-\mathrm{TAS}_{\mathrm{A}}
\end{aligned}
$$

From the densities measurments of solvents (MeOH-DMF) and the densities of $\mathrm{Cu}\left(\mathrm{NO}^{3}-\right)_{2}$ at different temperatures, the molar volumes $(\mathrm{V})$ were calculated and their values are listed in Table (1). The packing density $(\mathrm{P})$ as reported by Kim and Gomaa[14], i.e, the relation between Vander Waals volume (VW) and the molar volume (V) as shown in the following eq. (4).

$$
\mathrm{P}=\frac{\mathrm{V}_{\mathrm{W}}}{\mathrm{V}}=0.661 \pm 0.017
$$

The electrostrication volume (Ve), which is the volume compressed by the solvent can be calculated by using eq (5) as following:

$$
\mathrm{V}_{\mathrm{e}}=\left(\mathrm{V}_{\mathrm{W}}-\mathrm{V}\right)
$$

The apparent molar volumes $\left(\phi_{\mathrm{v}}\right)$ were also calculated by the following eq. (6)[15].

$$
\phi_{\mathrm{v}}=\frac{\mathrm{M}_{2}}{\mathrm{do}}-1000(\mathrm{~d}-\mathrm{do}) /\left(m_{S} \mathrm{ddo}\right)
$$

Where, $\left(\mathrm{M}_{2}\right)$ is the M.Wt of DMF, $\left(\mathrm{d}_{\mathrm{o}}\right)$ is the density of the solvent and (ms) is the molality .

The values of the solvated radius $\left(\mathrm{r}_{\mathrm{s}}\right)$ were calculated by using eq. (7) [ (Gomaa, (16)]

$$
\begin{gathered}
\mathrm{V}=\mathrm{N} \pi \sigma^{3} / 6 \\
\mathrm{r}_{\mathrm{s}}=\sigma / 2
\end{gathered}
$$


Table 1. The molar volume $(\mathrm{V})$, solvated Vander Waals $\left(\mathrm{V}_{\mathrm{W}}\right)$ and electrostriction volumes $\left(\mathrm{V}_{\mathrm{e}}\right)$ of $\mathrm{Cu}\left(\mathrm{NO}_{3}\right)_{2}$ in $(\mathrm{MeOH}-\mathrm{DMF})$ mixtures at different temperatures

\begin{tabular}{|c|c|c|c|c|c|c|c|c|c|c|c|c|}
\hline $\begin{array}{l}\text { Vol\% } \\
\text { MeoH }\end{array}$ & \multicolumn{4}{|c|}{$\mathrm{V}\left(\mathrm{cm}^{3} \cdot \mathrm{mol}^{-1}\right)$} & \multicolumn{4}{|c|}{$\mathrm{V}_{\mathrm{W}}\left(\mathrm{cm}^{3} \cdot \mathrm{mol}^{-1}\right)$} & \multicolumn{4}{|c|}{$\mathrm{Ve}\left(\mathrm{cm}^{3} \cdot \mathrm{mol}^{-1}\right)$} \\
\hline & $298.15 \mathrm{~K}$ & $303.15 \mathrm{~K}$ & $313.15 \mathrm{~K}$ & $313.15 \mathrm{~K}$ & $298.15 \mathrm{~K}$ & $303.15 \mathrm{~K}$ & $308.15 \mathrm{~K}$ & $313.15 \mathrm{~K}$ & $298.15 \mathrm{~K}$ & $303.15 \mathrm{~K}$ & $308.15 \mathrm{~K}$ & $313.15 \mathrm{~K}$ \\
\hline $\mathrm{O}$ & 77.20 & 77.81 & 77.90 & 78.52 & 51.02 & 51.43 & 51.49 & 51.90 & -26.18 & -26.38 & -26.41 & -26.62 \\
\hline 20 & 65.42 & 65.91 & 65.99 & 66.33 & 43.24 & 43.56 & 43.61 & 43.84 & -22.18 & -22.35 & -22.38 & -22.49 \\
\hline 40 & 55.45 & 55.88 & 56.07 & 56.40 & 36.65 & 36.93 & 37.06 & 37.28 & -18.8 & -18.95 & -19.01 & -19.12 \\
\hline 100 & 40.76 & 41.16 & 41.26 & 41.47 & 26.94 & 27.20 & 27.27 & 27.41 & -13.02 & -13.96 & -13.99 & -14.06 \\
\hline
\end{tabular}

Table 2. The apparent molar volumes $\left(\varphi_{v}\right)$, the solvated radius $\left(\mathrm{r}_{\mathrm{s}}\right)$ and the apparent molar volume at infinite dilution $\left(\varphi_{v}^{o}\right)$ of $\mathrm{Cu}(\mathrm{NO})_{2}$ in $(\mathrm{MeOH}-\mathrm{DMF})$ mixtures at different temperatures

\begin{tabular}{|c|c|c|c|c|c|c|c|c|c|}
\hline Vol\% MeoH & \multicolumn{4}{|c|}{$\varphi_{V \times 10^{3}}$} & \multicolumn{4}{|c|}{$\mathrm{r}_{\mathrm{s}} \times 10^{-8}$} & $\varphi^{\circ}$ \\
\hline & $298.15 \mathrm{~K}$ & $303.15 \mathrm{~K}$ & $308.15 \mathrm{~K}$ & $313.15 \mathrm{~K}$ & $298.15 \mathrm{~K}$ & $303.15 \mathrm{~K}$ & $308.15 \mathrm{~K}$ & $313.15 \mathrm{~K}$ & \\
\hline 0 & -7.84 & 18.67 & -30.63 & 26.87 & 3.12 & 3.14 & 3.14 & 3.15 & 16 \\
\hline 20 & 21.86 & 46.62 & 2.83 & 2.84 & 2.96 & 2.96 & 2.97 & 2.97 & 32 \\
\hline 40 & -193.78 & -155.17 & -167.18 & -169.64 & 2.80 & 2.80 & 2.81 & 2.82 & -40 \\
\hline 100 & 30.24 & 68.76 & 38.614 & 9.795 & 2.52 & 2.54 & 2.54 & 2.54 & -3 \\
\hline
\end{tabular}

Table 3. The values of $\mathrm{C}, \Lambda, \Lambda$, $\mathrm{S}(\mathrm{z}), \gamma \pm, \alpha, K_{A}$ and $\Delta \mathrm{G}$ of $\mathrm{Cu}\left(\mathrm{NO}_{3}\right)_{2}$ in mixed (MeOH-DMF) solvents at different temperatures using Fuoss Shedlovesky method

\begin{tabular}{|c|c|c|c|c|c|c|c|c|}
\hline Vol\% of $\mathrm{MeOH}$ & $\mathrm{C}_{\mathrm{m}} \times 10^{-5}$ & $\Lambda$ & $\Lambda_{\mathrm{o}}$ & $\gamma \pm$ & $\alpha$ & $\mathrm{S}(\mathrm{z})$ & $\mathrm{K}_{\mathrm{A}} \times 10^{6}$ & $-\Delta G$ \\
\hline 0 & 8.0 & 154.4 & 175 & 0.9438 & 0.882 & 1.0 & 7.52 & 39.25 \\
\hline 20 & 8.0 & 116.3 & 132.5 & 0.9396 & 0.877 & 1.0 & 7.99 & 39.40 \\
\hline 40 & 8.0 & 149.4 & 170 & 0.9361 & 0.878 & 1.0 & 7.95 & 39.39 \\
\hline 100 & 8.0 & 158.8 & 180 & 0.9284 & 0.882 & 1.0 & 7.77 & 39.34 \\
\hline \multicolumn{9}{|l|}{ b) at $303.15 \mathrm{~K}$} \\
\hline Vol\% of $\mathrm{MeOH}$ & $\mathrm{C}_{\mathrm{m}} \times 10^{-5}$ & $\Lambda$ & $\Lambda_{\mathrm{o}}$ & $\gamma \pm$ & $\alpha$ & $\mathrm{S}(\mathrm{z})$ & $\mathrm{K}_{\mathrm{A}} \times 10^{6}$ & $-\Delta \mathrm{G}$ \\
\hline 0 & 8.0 & 108 & 122 & 0.9428 & 0.885 & 1.0 & 7.26 & 39.82 \\
\hline 20 & 8.0 & 103.9 & 118 & 0.9386 & 0.881 & 1.0 & 7.76 & 39.99 \\
\hline 40 & 8.0 & 151 & 172 & 0.9351 & 0.878 & 1.0 & 8.06 & 40.08 \\
\hline 100 & 8.0 & 155.5 & 176 & 0.9271 & 0.884 & 1.0 & 7.67 & 39.96 \\
\hline \multicolumn{9}{|l|}{ c) at $308.15 \mathrm{~K}$} \\
\hline $\mathrm{Vol} \%$ of $\mathrm{MeOH}$ & $\mathrm{C}_{\mathrm{m}} \times 10^{-5}$ & $\Lambda$ & $\Lambda_{\mathrm{o}}$ & $\gamma \pm$ & $\alpha$ & $\mathrm{S}(\mathrm{z})$ & $\mathrm{K}_{\mathrm{A}} \times 10^{6}$ & $-\Delta G$ \\
\hline 0 & 8.0 & 230 & 265 & 0.9417 & 0.867 & 1.0 & 8.89 & 40.99 \\
\hline 20 & 8.0 & 130.6 & 155 & 0.9379 & 0.842 & 1.0 & 11.68 & 41.69 \\
\hline 40 & 8.0 & 162.5 & 190 & 0.9337 & 0.855 & 1.0 & 10.36 & 41.39 \\
\hline 100 & 8.0 & 169.6 & 197.5 & 0.9254 & 0.858 & 1.0 & 10.17 & 41.34 \\
\hline \multicolumn{9}{|l|}{ d) at $313.15 \mathrm{~K}$} \\
\hline $\mathrm{Vol} \%$ of $\mathrm{MeOH}$ & $\mathrm{C}_{\mathrm{m}} \times 10^{-5}$ & $\Lambda$ & $\Lambda_{\mathrm{o}}$ & $\gamma \pm$ & $\alpha$ & $\mathrm{S}(\mathrm{z})$ & $\mathrm{K}_{\mathrm{A}} \times 10^{6}$ & $-\Delta G$ \\
\hline 0 & 8.0 & 332 & 275 & 0.9402 & 0.844 & 1.0 & 11.50 & 42.33 \\
\hline 20 & 8.0 & 130 & 160 & 0.9365 & 0.813 & 1.0 & 15.57 & 43.12 \\
\hline 40 & 8.0 & 168.5 & 205 & 0.9322 & 0.822 & 1.0 & 14.41 & 42.92 \\
\hline 100 & 8.0 & 174 & 210 & 0.9234 & 0.828 & 1.0 & 13.80 & 42.81 \\
\hline
\end{tabular}

$\mathrm{C}$ in (mol./1.); $\Lambda$ \& $\Lambda_{\mathrm{o}}$ in $(\Omega-1 . \mathrm{cm} 2 . \mathrm{mol}-1) ; \mathrm{KA}$ in (mol./1.); $\Delta \mathrm{G}$ in $(\mathrm{Kj} . \mathrm{mol}-1)$

Table 4. The Values of $\mathrm{C}, \Lambda, \Lambda_{\mathrm{o}}, \gamma \pm \mathrm{S}(\mathrm{z}), \alpha, \mathrm{K}_{\mathrm{A}}$ and $\Delta \mathrm{G}$ of Cu(NO$)_{2}$ in presence of Kryptofix-221 and in (MeOH-DMF) mixtures, at different temperatures using Fuoss-Sheslovesky method

a) at $298.15 \mathrm{~K}$

\begin{tabular}{|c|c|c|c|c|c|c|c|c|}
\hline $\mathrm{Vol} \%$ of $\mathrm{MeOH}$ & $\mathrm{C}_{\mathrm{m}} \times 10^{-5}$ & $\Lambda$ & $\Lambda_{\mathrm{o}}$ & $\gamma \pm$ & $\mathrm{S}(\mathrm{z})$ & $\alpha$ & $\mathrm{K}_{\mathrm{A}} \times 10^{6}$ & $-\Delta \mathrm{G}$ \\
\hline 0 & 8.0 & 658.3 & 760 & 0.9418 & 1.0066 & 0.872 & 9.008 & 39.702 \\
\hline 20 & 8.0 & 246.7 & 410 & 0.9474 & 1.0085 & 0.606 & 78.89 & 39.89 \\
\hline 40 & 8.0 & 33 & 46.7 & 0.9373 & 1.0092 & 0.713 & 36.63 & 39.86 \\
\hline 100 & 8.0 & 546.7 & 640 & 0.9258 & 1.0083 & 0.861 & 10.57 & 40.09 \\
\hline
\end{tabular}

b) at $303.15 \mathrm{~K}$

\begin{tabular}{|c|c|c|c|c|c|c|c|c|}
\hline Vol\% of $\mathrm{MeOH}$ & $\mathrm{C}_{\mathrm{m}} \times 10^{-5}$ & $\Lambda$ & $\Lambda_{\mathrm{o}}$ & $\gamma \pm$ & $\mathrm{S}(\mathrm{z})$ & $\alpha$ & $\mathrm{K}_{\mathrm{A}} \times 10^{6}$ & $-\Delta \mathrm{G}$ \\
\hline 0 & 8.0 & 875 & 780 & 0.9436 & 1.0 & 0.865 & 9.11 & 40.39 \\
\hline 20 & 8.0 & 308.5 & 370 & 0.9403 & 1.0 & 0.833 & 12.66 & 43.87 \\
\hline 40 & 8.0 & 297.5 & 345 & 0.9358 & 1.0 & 0.862 & 9.57 & 42.76 \\
\hline 100 & 8.0 & 467.5 & 740 & 0.9382 & 1.0 & 0.631 & 64.66 & 45.34 \\
\hline
\end{tabular}


c) at $308.15 \mathrm{~K}$

\begin{tabular}{|c|c|c|c|c|c|c|c|c|}
\hline $\mathrm{Vol} \%$ of $\mathrm{MeOH}$ & $\mathrm{C}_{\mathrm{m}} \times 10^{-5}$ & $\Lambda$ & $\Lambda_{\mathrm{O}}$ & $\gamma \pm$ & $\mathrm{S}(\mathrm{z})$ & $\alpha$ & $\mathrm{K}_{\mathrm{A}} \times 10^{6}$ & $-\Delta \mathrm{G}$ \\
\hline 0 & 8.0 & 665 & 790 & 0.8426 & 1.0 & 0.841 & 11.66 & 41.69 \\
\hline 20 & 8.0 & 290 & 380 & 0.9409 & 1.0 & 0.763 & 23.512 & 44.21 \\
\hline 40 & 8.0 & 275 & 370 & 0.9381 & 1.0 & 0.743 & 27.75 & 43.34 \\
\hline 100 & 8.0 & 452.5 & 680 & 0.9342 & 1.0 & 0.665 & 50.82 & 45.46 \\
\hline
\end{tabular}

d) at $313.15 \mathrm{~K}$

\begin{tabular}{|c|c|c|c|c|c|c|c|c|}
\hline $\mathrm{Vol} \%$ of $\mathrm{MeOH}$ & $\mathrm{C}_{\mathrm{m}} \times 10^{-5}$ & $\Lambda$ & $\Lambda_{\mathrm{o}}$ & $\gamma \pm$ & $\mathrm{S}(\mathrm{z})$ & $\alpha$ & $\mathrm{K}_{\mathrm{A}} \times 10^{6}$ & $-\Delta \mathrm{G}$ \\
\hline 0 & 8.0 & 655 & 780 & 0.9404 & 1.0 & 0.839 & 11.95 & 42.43 \\
\hline 20 & 8.0 & 288 & 364 & 0.9374 & 1.0 & 0.791 & 18.73 & 42.69 \\
\hline 40 & 8.0 & 280 & 346 & 0.9328 & 1.0 & 0.809 & 16.15 & 42.61 \\
\hline 100 & 8.0 & 462 & 380 & 0.9250 & 1.0 & 0.822 & 14.56 & 42.94 \\
\hline
\end{tabular}

$\mathrm{C}$ in (mol./1.); $\Lambda \& \Lambda_{\mathrm{o}}$ in $\left(\Omega^{-1} \cdot \mathrm{cm}^{2} \cdot \mathrm{mol}^{-1}\right) ; \mathrm{K}$ in $(\mathrm{mol} . / \mathrm{l}.) ; \Delta \mathrm{G}$ in $\left(\mathrm{Kj} \mathrm{Mol}^{-1}\right)$

Where $(\mathrm{V})$ is the molar volume, $(\mathrm{N})$ is Avogadro's number and $(\sigma)$ is the diameter, the evaluated data are given in Table(2).

The experimental condctometric data of the equivalent measurements of $\mathrm{Cu}\left(\mathrm{NO}_{3}\right)_{2}$ in mixed solvents were analyzed using Shedlovsky and Fuoss - Kraus extrapolation techniques which have been mentioned earlier in Dash's publication[17] as given.

$$
\frac{1}{\Lambda S(z)}=\frac{1}{\Lambda_{o}}+\frac{K_{A}}{\Lambda_{o}^{2}}\left[C \Lambda \gamma^{2} S(z)\right]
$$

Where $\mathrm{S}(\mathrm{z})=1+\mathrm{Z}+\mathrm{Z}^{2} / 2+\mathrm{Z}^{3} / 3+$ etc

$$
(\mathrm{Z})={\frac{\mathrm{S}(\mathrm{C})}{\Lambda_{\mathrm{o}}{ }^{3 / 2}}}^{1 / 2} \Lambda
$$

Where $\mathrm{S}=\mathrm{a} \Lambda_{\mathrm{o}}+\mathrm{b}, \mathrm{a}=8.2 \times 10^{5} /(\Lambda \varepsilon \mathrm{T})^{3 / 2}, \mathrm{~b}=$ o. 825

$$
\begin{aligned}
& \eta_{o}(\varepsilon T)^{1 / 2} \\
& \text { and } \\
& \log \gamma \pm=-\mathrm{A}(\alpha \mathrm{C})^{1 / 2}\left[1+\mathrm{Br}^{\mathrm{o}}(\alpha \mathrm{C})^{1 / 2}\right] \\
& \alpha=\Lambda \mathrm{S}(\mathrm{z}) / \Lambda_{\mathrm{o}}
\end{aligned}
$$

Where (A) and (B) are the Debye-Huckel constants, $\left(\mathrm{r}^{\circ}\right)$ is the ion size parameter, $\left(\eta_{o}\right)$ and $(\varepsilon)$ are the viscosity and the dielectric constants of the MeOH-DMF mixed solvent, respectively. All the parameters calculated by Shedlovesky methode at different temperatures are given in Tables (3), (4).

Table (5) (a,b,c), illustrated the thermodynamic parameters $\left(\eta_{o} \Delta \mathrm{G}_{\mathrm{s}}\right),\left(\Delta \mathrm{H}_{\mathrm{s}}\right)$ and $(\mathrm{T} \Delta \mathrm{S})$ of the solvation of $\mathrm{Cu}\left(\mathrm{NO}_{3}\right)_{2}$ with $(\mathrm{MeOH}-\mathrm{DMF})$ in presence and absence of Kryptofix-221.

All their values were calculated from the solubilites measurements. The $\left(\Delta \mathrm{G}_{\mathrm{s}}\right)$ values found to be increased by increasing the content of the organic solvent (MeOH-DMF) mixtures.

On the other hand, the values of $(\Delta \mathrm{H})_{\mathrm{s}}$ and $(\mathrm{T} \Delta \mathrm{S})_{\mathrm{s}}$ were generally found to be decreased by increasing the methanol content in the mixtures used.

It was concluded from Table (6), that, the association constant $\left(\mathrm{K}_{\mathrm{A}}\right)$ of $\mathrm{Cu}\left(\mathrm{NO}_{3}\right)_{2}$ in presence and absence of Kryptofix-221 in (MeOH - DMF) mixtures, at different temperatures, using the different methods [Fuoss Shedlovesky and Fuoss- Kraus] have nearly the same values.
This indicates that, the association constants in this case are due to the formation of different stiochiometric complexes as mentioned in this table. The formation of these complexes are probably be outside the Kryptofix ring.

The graphical presentation of the relation between $\log \mathrm{K}_{\mathrm{A}}$ and the inverse temperatures $\left(\frac{1}{T}\right)$ at different temperatures, give slope and from their slopes, we can calculate the thermodynamic parameters $\left(\Delta \mathrm{H}_{\mathrm{A}}\right)$.

Also, we plot the relation between $\log \Lambda_{\mathrm{o}}$ and $\left(\frac{1}{T}\right)$ in presence and absence of Kryptofix-221.

The graphical presentation of the relation between the association free energies $\left(\Delta G_{A}\right)$ and the mole fraction $(X s)$ of the organic solvent used at different temperatures at four different mole fraction of $\mathrm{Cu}\left(\mathrm{NO}_{3}\right)_{2}$ and Kryptofix-221 are show in .

Also the graphical presentation of the relation between the apparent molar volume $\left(\varphi_{v}\right)$ and $(\sqrt{\mathrm{ms}})$, where $(\sqrt{\mathrm{ms}})$ in the molality shown in .

\section{Conclusions}

It was concluded that, the $\mathrm{K}_{\mathrm{A}}$ association of metal cation with Kryptofix increase with increase of temperatures and also, with increase of the methanol content in the mixtures due to the increase of ion-ion and ion-solvent interactions. KA values increased by increase methanol content in the mixed solvents due to the preferential slovation of cupper with methanol than the mixed solvent and dimethyl formamide. $\mathrm{K}_{\mathrm{A}}$ values increase also by increasing temperatures due mainly to the increase in kinetic energy and kinetic work necessary to do salvation process. Log $\mathrm{K}_{\mathrm{A}}$ values calculated by different methods indicate that the values are small in case of Fuoss and Fuoss-Kraus methods in comparison to that values which have calculated. Therefore our values are near to the true picture of the greater ions. It was also concluded that the free energies of complexation increase with increase in methanol content due to the increase of interaction of the divalent metal cation with Kryptofix-221. According to the too low concentration used, the entropy parameter show no significant rule in this work. 
Table 5. The values of $\Delta \mathrm{G}, \Delta \mathrm{H}$ and $\mathrm{T} \Delta \mathrm{S}$ of $\mathrm{Cu}\left(\mathrm{NO}_{3}\right)_{2}$ in mixed (MeOH-DMF) solvents in presence and absence of Kryptofix-221 at different temperatures

\begin{tabular}{|c|c|c|c|c|c|c|c|c|c|c|}
\hline \multirow{2}{*}{ Vol\% $\%$ MeOH } & \multicolumn{4}{|c|}{$\Delta \mathrm{G}_{\mathrm{A}} \times 10^{3}\left(\mathrm{~J} \cdot \mathrm{mol}^{-1}\right)$} & \multicolumn{4}{|c|}{$\left(\Delta \mathrm{G}_{\mathrm{S}}\right) \times 10^{3}\left(\mathrm{~J} \cdot \mathrm{mol}^{-1}\right)$} & \multirow{2}{*}{$\begin{array}{c}(\Delta \mathrm{H})_{\mathrm{A}} \times \\
10^{3}\left(\mathrm{~J}_{\mathrm{mol}}{ }^{-1}\right) \\
\end{array}$} & \multirow{2}{*}{$\begin{array}{c}(\Delta \mathrm{H})_{\mathrm{s}} \times 10^{3} \\
\left(\mathrm{~J} \cdot \mathrm{mol}^{-1}\right)\end{array}$} \\
\hline & $298.15 \mathrm{k}$ & $303.15 \mathrm{k}$ & $308.15 \mathrm{k}$ & $313.15 \mathrm{k}$ & $298.15 \mathrm{k}$ & $303.15 \mathrm{k}$ & $308.15 \mathrm{k}$ & $313.15 \mathrm{k}$ & & \\
\hline 0 & -39.7 & -40.39 & -41.69 & -42.43 & -39.25 & -39.82 & -40.99 & -42.33 & -14.36 & -22.73 \\
\hline 20 & -39.89 & -43.87 & -44.21 & -42.69 & -39.40 & -39.99 & -41.69 & -43.12 & -15.79 & -34.7 \\
\hline 40 & -39.86 & -42.76 & -43.34 & -42.61 & -39.39 & -40.08 & -41.39 & -42.92 & -14.36 & -29.91 \\
\hline 100 & -40.09 & -45.34 & -45.46 & -42.94 & -39.34 & -39.96 & -41.34 & -42.81 & -16.75 & -29.91 \\
\hline \multicolumn{11}{|l|}{ b) } \\
\hline $\mathrm{Vol} \% \mathrm{MeOH}$ & \multicolumn{5}{|c|}{$(\mathrm{T} \Delta \mathrm{S})_{\mathrm{A}} \times 10^{3}\left(\mathrm{~J} \cdot \mathrm{mol}^{-1}\right)$} & \multicolumn{5}{|c|}{$(\mathrm{T} \Delta \mathrm{S})_{\mathrm{S}} \times 10^{3}\left(\mathrm{~J}_{\mathrm{mol}} \mathrm{mol}^{-1}\right)$} \\
\hline & $298.15 \mathrm{k}$ & \multicolumn{2}{|c|}{$303.15 \mathrm{k}$} & $308.15 \mathrm{k}$ & $313.15 \mathrm{k}$ & $298.15 \mathrm{k}$ & $303.15 \mathrm{k}$ & $308.15 \mathrm{k}$ & \multicolumn{2}{|r|}{$313.15 \mathrm{k}$} \\
\hline 0 & \multicolumn{2}{|l|}{16.52} & .09 & 18.26 & 19.06 & 25.34 & 26.03 & 27.33 & & 28.07 \\
\hline 20 & 4.7 & & & 6.99 & 8.42 & 24.1 & 28.08 & & & 26.9 \\
\hline 40 & 9.48 & & & 11.48 & 13.01 & 25.5 & 28.4 & & 98 & 28.25 \\
\hline 100 & 9.43 & & & 11.43 & 12.09 & 23.34 & 28.59 & & 71 & 26.19 \\
\hline
\end{tabular}

c) The values of $(\Delta \mathrm{G}) \mathrm{c}$ of the complexation of $\mathrm{Cu}\left(\mathrm{NO}_{3}\right)_{2}$ with kryptofix-221 in mixed (MeOH-DMF) solvents at different temperatures.

\begin{tabular}{|c|c|c|c|c|}
\hline & \multicolumn{4}{|c|}{$(\Delta \mathrm{G})_{\mathrm{c}} \times 10^{3}\left(\mathrm{~J} \cdot \mathrm{mol}^{-1}\right)$} \\
\hline $\mathrm{Vol} \% \mathrm{MeOH}$ & $298.15 \mathrm{k}$ & $303.15 \mathrm{k}$ & $308.15 \mathrm{k}$ & $313.15 \mathrm{k}$ \\
\hline 0 & -0.452 & -0.57 & -0.7 & -0.1 \\
\hline 20 & -0.49 & -3.88 & -2.52 & -0.43 \\
\hline 40 & -0.47 & -2.68 & -1.95 & -0.31 \\
\hline 100 & -0.75 & -5.38 & -4.12 & -0.13 \\
\hline
\end{tabular}

Table 6. The values $\mathrm{Log} \mathrm{K}_{\mathrm{A}}$ of $\mathrm{Cu}\left(\mathrm{NO}_{3}\right)_{2}$ in presence of Kryptofix -221 and in (MeOH-DMF) at different temperatures using different methods

\begin{tabular}{|c|c|c|c|c|c|c|c|c|c|c|c|c|}
\hline $\begin{array}{l}\text { Vol \% } \\
\text { MeoH }\end{array}$ & \multicolumn{4}{|c|}{$\log \mathrm{K}_{\mathrm{A}}$ complex } & \multicolumn{4}{c|}{$\log \mathrm{K}_{\mathrm{A}}$ F-shedlovesky } & \multicolumn{4}{c|}{$\log \mathrm{K}_{\mathrm{A}}$ F-kraus } \\
\hline & $298.15 \mathrm{~K}$ & $303.15 \mathrm{~K}$ & $313.15 \mathrm{~K}$ & $313.15 \mathrm{~K}$ & $298.15 \mathrm{~K}$ & $303.15 \mathrm{~K}$ & $308.15 \mathrm{~K}$ & $313.15 \mathrm{~K}$ & $298.15 \mathrm{~K}$ & $303.15 \mathrm{~K}$ & $308.15 \mathrm{~K}$ & $313.15 \mathrm{~K}$ \\
\hline $\mathrm{O}$ & 6.95 & 6.96 & 7.06 & 7.07 & 3.46 & 3.37 & 3.46 & 3.47 & 3.170 & 3.051 & 3.11 & 3.19 \\
\hline 20 & 6.98 & 7.55 & 7.49 & 7.12 & 3.73 & 3.49 & 2.73 & 3.64 & 2.88 & 2.89 & 2.78 & 3.20 \\
\hline 40 & 6.98 & 7.36 & 7.35 & 7.11 & 3.79 & 3.38 & 3.79 & 3.58 & 2.82 & 3.36 & 2.60 & 2.76 \\
\hline 100 & 7.02 & 7.8 & 7.7 & 7.16 & 4.01 & 4.09 & 4.01 & 3.63 & 4.29 & 4.40 & 4.23 & 3.81 \\
\hline
\end{tabular}

$\mathrm{K}_{\mathrm{A}}$ in $(\mathrm{mol} / \mathrm{L})$

[9] Poonia N.S.; Bajai A.V, Coordination Chemistry of Alkaline and Alkali Earth Cations, Chem. Rev, 79. (1979), 389

\section{REFERENCES}

[1] Pedersen C.J. (1967) Am. Chem. SoC.89.7017

[2] Lehn J.M.; Sauvage J.P. (1971) Chem. Comm., 440

[3] Dietrich B.; Lehn J.M. and Sauvage J.P. (1969) Tetrahedran Lett., $2885 \& 2889$

[4] Gokel G. W.; Durst H.D. (1976) Synthesis, 168

[5] Izatt R.M.; Izatt N.E.; Rossiter B.E.; Christensen J.J. and Haymore B.L. (1978) Science 199,994

[6] El-Dossouki F.I. (1998) Ph.D. Thesis; Mansoura University; Egypt

[7] Rounaghi G.; Nejad F.M. and Taheri K. (1999) Ind. J.Chem. 38A, 568

[8] Mukhopadhyay A.; Chattopadhyay M.R. and Pal M. (1997) Ind. J.Chem. 36A, 94
[10] Shamsipur M.; Ghasem; J, J Inclusion Phenom Mol Recognit Chem, 20(2), (1995), 157

[11] Fouss R.M.; Edelson D. (1951) J.Am.Chem.Soc.73,269

[12] Bel'sky K.V., Chem Rev, 68(2), (1999). 119

[13] Kappenstein C. (1974) Bull. Soc.Chim. Fr. 89,101

[14] Kim J.I, Zeitschrift Fur Physikalische Chemie Neue Folge, 110, (1978), 197and Gomaa E.A.Thermochim.Acta ,152 (198) 371

[15] Gryblavwski W.; Pastewslai Electro Chimice Acta, 25(1980) 279

[16] Gomaa E.A., Therm.Chim. Acta, 152 (1989) 71

[17] Dash N.U; Pasupalak N.N, Ind. J.Chem, 36(A), (1997) 88 